\title{
Drivers of Impulse Buying at Retail Stores: Mediating Role of Customers' Loyalty
}

\author{
Mohamed Ismail Mujahid Hilal ${ }^{1} \&$ Selvaratnam Gunapalan ${ }^{1}$ \\ ${ }^{1}$ Faculty of Management and Commerce, South Eastern University of Sri Lanka, Oluvil, Sri Lanka \\ Correspondence: Mohamed Ismail Mujahid Hilal, Department of Management, South Eastern University of Sri \\ Lanka, Oluvil, Sri Lanka. E-mail: mujahidh@seu.ac.lk
}

Received: June 12, 2019

Accepted: June 30, 2019 Online Published: July 5, 2019

doi:10.5539/ass.v15n8p1

URL: https://doi.org/10.5539/ass.v15n8p1

\begin{abstract}
The major objective of this study was to examine the impact of drivers of impulse buying on the customers' loyalty and to assess the mediating effect of customers' loyalty to the impulse buying at the retail stores. In order to meet the objective, a questionnaire survey was conducted among 529 customers of retail stores. SMARTPLS3 was used to analyze the data collected from the survey. Findings suggest that CSR, store attractiveness and trust positively contribute to create loyalty of retailers and it positively impact on impulse buying at stores. The model tested in this study was significant and can be used by retailers to enjoy competitive advantage. Further, it was found that loyalty is mediating between these drivers of impulse buying and impulse buying. While loyalty positively mediating between all variables, loyalty negatively mediates between commitment and impulse buying. The model tested in this study is significant and useful for retailers to create loyalty and trigger impulse buying enabling to achieve competitive advantage in retailing. When retailers adopt this model in their business, retailers can establish loyalty and generate impulse buying. Therefore, retailers need to build up trust among customers, engaging in CSR activities, keeping their stores very attractive and having long term relationship to create commitment with customers.
\end{abstract}

Keywords: CSR, trust, impulse buying, loyalty, store attractiveness, retailers

\section{Introduction}

In retail marketing, stores' services are vital component in achieving competitive advantages due to expectations of retail customers (Torlak et al., 2010). Impulse buying defined as unplanned purchasing by customers in any outlets irrespective of size of the retailers. Impulse buying is generally taking place owing to designing the store (store environment), enjoying the shopping, displaying product, promotional aspects and pricing (Beatty and Ferrell, 1998). Consumers visit stores for their daily needs and make purchase at the stores. However, they are sometimes purchase goods impulsively due to their reference group and impulse buying tendency (Badgaiyan \& Verma, 2014). In the case of the marketing, impulse buying is one of the important aspects of the marketing activities due to the differences in impulse buying according to the varieties of product (Sharma et al., 2010).

Store attractiveness is one of the important factors that influence the loyalty and be the reason for the impulse buying. According to El-Adly (2007), comfort, entertainment, diversity, mall essence, convenience and luxury are important attributes of store attractiveness. Retailers' trust is also one of the vital factors that create customers' loyalty. Trust should be created in the mind of customers with regard to the retailer from whom they make purchase. Shainesh (2012) validates that trust is one of the most eminent factors creating the loyalty among customers on the stores. Retailers also need CSR activities to enjoy competitive advantage (Hafez, 2018) which may enable retailers to gain from the loyalty. Firms' CSR activities can be classified as ethical, legal and economical CSR activities. Ethical CSR activities of the firm can contribute to the brand equity of the firm (Tuan, 2012). Examining the impact of CSR on the customers' loyalty is famous as studies on CSR lack in developing nation (Hafez, 2018). Commitment towards retailers is another factor that causes customers' loyalty. Commitment is considered to be a major driver of customer responses (Jones et al., 2010). Commitment is strongly associated with customer loyalty (Dagger et al., 2011). Hence, it is essential to look into the retailer's commitment towards customers enabling them to attract more customers towards retail stores.

Sri Lankan retail sectors is growing exponentially now with the concept of self-selection supermarket stores (Hilal \& Mubarak, 2015). Consumers prefer to do shopping in an environment where they need more enjoyment 
and the experience shopping leisurely. While the retailing is growing in Sri Lanka, there is a requirement of evaluating the customers' loyalty derived from store attractiveness, retailers' trust, retailers' corporate social responsibility and retailers' commitment. This is because, these factors help retailers to enjoy competitive advantage in the retail sector in Sri Lanka. Nowadays, consumers' purchasing power make them as more powerful than the retailers and hence, they give more importance on the values on the product and the service given to them. Thus, retailers are required to improve their strategies and need to avoid the capture by competitors (Torlak et al., 2010). Researcher conducted 20 interviews in relation to these four factors and its contribution to loyalty. Interviews results reveal that retailers engage in all four activities and it positively related to customers' loyalty. In addition, it is sensible to note here that it is very rare to find studies on the variables under study in Sri Lankan context. Hence, it is very significant to explore relationship between the factors such as retailers trust, commitment, CSR, and store attractiveness and customers' loyalty. This will also lead to impulse buying which is one of the sources of competitive advantage for retailers. Further, the study on impulse buying contribute to the significance of the retail industry by giving experience marketing activities that could be improved and positively impact on the impulse buying performance (Deng \& Moutinho, 2015). Therefore, assessing all four factors and its contribution to the loyalty is now one of major concern of academics. Thus, the research questions of this study were does the store attractiveness, retailers' trust, retailers' CSR activities and their commitment influence the customers' loyalty? Does the customers' loyalty positively impact on the impulse buying of customers? Therefore, the major objective of this study was to examine the impact of drivers of impulse buying on the customers' loyalty. The other objective was to assess the mediating effect of customers' loyalty to the impulse buying at the retail stores.

\section{Review of Literature and Theoretical Framework}

\subsection{Impulse Buying}

Impulse buying is lucrative for businesses as customers buy additional products while shopping (Babin \& Attaway, 2000). Impulse buying is defined as buying product without any pre intention (Beatty \& Ferrell, 1998) and it is not considered as wrong matter for consumers (Hausman, 2000). Retailers use showgirls to promote their products. Positive relationship is being found when a product is promoted using showgirls and impulse buying in stores (Tsao, 2013). Studies found that there is a direct links between goals conflicts and impulse buying. Customers who will have a goals of saving money will not engage in impulse purchasing and even when customers are with saving goals may simultaneously try to spend or keep materials in possession (Robert \& Manolis, 2012).

In order for the impulse buying takes place in stores, there may be requirements that customers should enjoy the shopping within the store. This tendency of shopping enjoyment impacts positively on the impulse buying (Atulkar \& Kesari, 2018). Enjoyment tendency may include music, lights, employees and layouts (Mohan et al., 2013). A music tempo positively influences the impulse buying (Ju \& Ahn, 2016; Shuleska, 2012). The positive relationship between store environment consisting of enjoyment tendency and impulse buying was not supported in a study (Atulkar \& Kesari, 2018). Impulse buying to be happened in a store environment may depend on many factors such as shopping enjoyment tendency, situation of the person who is going for shopping, activities to motivate impulse buying by the retailers and product attributes (Atulkar \& Kesari, 2018). However, there are hedonic shopping values which also impacts on impulse purchasing intentions. For example, fun, novelty, escapism, social interaction (Ju \& Ahn, 2016) and praise from others. These factors positively influence the impulse purchasing intentions. However, the situational factors such as money availability, time availability and task definition moderate the relationship between shopping values and impulse purchasing intentions (Dey \& Srivastava, 2017). Further, it was also found that emotion of the customer, self-esteem and life satisfaction positively influence the impulse buying (Nayebzadesh \& Jalaly, 2014).

Customers' happy, satisfaction with stores and their relax are important for competitive advantage. This can be realized with the help of improving the impulse buying at stores. This is due to the fact that stores should be designed integrating the experience marketing activities in which customers' involvement should be encouraged (Deng \& Moutinho, 2015). When designing the stores, retailers may consider the factors such as young and adults characteristics that motivate the impulse buying. It is evident that adults understand their situation even during the impulse buying when compared to young consumers (Brici et al., 2013).

\subsection{Retailers' Commitment}

Retailers commitment is one of the important factors in creating loyalty and in turn influencing the impulse buying. Commitment is developing long term stability in the relationship (Anderson \& Weitz, 1992). Retailers commitment refers to development of long-term relationship by retailers with customers. Commitment of 
retailers depends on investing relationship, communication and on the management of the organization. The commitment is also increased when there is higher relationship investment and good communication (Dagger et al., 2011). While considering the new paradigm shift in the retailing (Kandampully, 2006), service organizations (retailers) need to pay greater attention on the investment in customer relationship management that may help further improve commitment of retailers as these could be indicators for commitment (Dagger et al., 2011).

Organizational design comprising logo, name etc. provide control communication which may positively exert an influence on the perception of consumers. The culture of the retail organization is also considered as impacting on the commitment. Hence, it was found that customer perception with regard to control communication will have positive effect on commitment (Melewar et al., 2017). Further, in a study (Tabrani et al., 2018), find that trust is also one of the important factors that create commitment. That is, trust enhances the commitment and in turn positively impact on the customer loyalty (Tabrani et al., 2018). Further, the brand commitment and impulse buying have positive relationship in accordance with gender differences. Brand commitment possessed by women have will have positive effect on impulse buying (Tifferet \& Herstein, 2012).

When understanding the literature, relationship marketing and control communication as commitment to the retailers are playing important role in creating customers' loyalty. This is because of the fact that the organization's profit, in fact, is derived with strong association with customers (Hur et al., 2011). This was also confirmed with the finding of a positive relationship has been found between commitment and loyalty by Dagger et al., (2011) and Kaur and Soch (2018). Thus, researcher hypothesizes that

$\mathrm{H}_{1}$ : Retailers' commitment towards customers positively influence the customers' loyalty.

$\mathrm{H}_{1 \mathrm{a}}$ : Retailers' commitment towards customers positively influence the impulse buying at the store

$\mathrm{H}_{1 \mathrm{~b}}$ : Loyalty complementarily mediates between commitment and impulse buying at retail stores

\subsection{Retailers Trust}

Trust help to get rid of risk or uncertainty associated with a transaction (Ring \& van de Ven, 1994). Trust is a confidence created on the reliability of the partner (Palmatier et al., 2006). It is also defined as willingness to be on the other party (McKnight et al., 2002). Trust plays a vital role in creating loyalty within novice and experience customers with differences. In the case of novice customers, customer satisfaction leads to loyalty. For the experience customers, trust is the most important factor that leads to the loyalty. This is because of the fact that trust can be created only with familiarity and rapports being developed within the party (Dagger et al., 2010). Customers previous experiences with shopping impact on the trust dimensions (Abbes \& Goudey, 2015). Trust, thus, leads to the development of loyalty intention and that contribute to the relationship marketing (Shainesh, 2012). Further, trust is playing a mediating role between attitudes and loyalty (Akhari et al., 2018). Retailers should exhibit integrity and ability to the customers to build trust. Retailers to boost the trust by engaging in activities related to integrity (Rampl et al., 2012). Although overall store trust consists of trust on salesperson and trust on store brands, store trust enhances the loyalty intention (Guenzi et al., 2009). Further, store environment is also positively impacting on the store trust and assortments in the store also create store trust (Guenzi et al., 2009).

Review of literature shows that retailers' trust has a relationship with customers' loyalty. When a customer is store loyalty with previous experience with the store, definitely will be able to make impulse buying at the store. Since, trust creates loyalty and loyalty and impulse buying has positive associations, it is likely that when customers have retailers' loyal, impulse purchasing is unavoidable. Therefore, researcher hypothesizes the followings;

$\mathrm{H}_{2}$ : Retailers' trust positively influence the customers' loyalty.

$\mathrm{H}_{2 \mathrm{a}}$ : Retailers' trust the customer has positively influence the impulse buying at the store

$\mathrm{H}_{2 \mathrm{~b}}$ : Loyalty complementarily mediates between trust and impulse buying

\subsection{Store Attractiveness}

Store attractiveness is also one of important determinants of the store loyalty among the customers. Stores should be comfortable with entertainment, with diversity and mall essence and it should have convenience with luxury (El-Adly, 2007). The impact of attractiveness is depending on number of visits of customers, how long do they are retained at the stores and how much spent at each visit to the stores (Anselmsson, 2006). Retailers need to enhance the attractiveness by utilizing experiences for the customers. This can be done by managing tenant, facilities, atmosphere and entertainment at the stores. This would also be the indicators of shopping experience (Tandon et al., 2016). 
According to literature, store attractiveness includes comfortable, entertainment, convenience and luxury. This has to be improved and it create store loyalty for customers (Wahlberg, 2016). Store attractiveness along with attractive store environment including store display, promotional materials, behaviour of the staff and price well determines the impulse buying in a store (Tendai \& Crispen, 2009). Further, it was also confirmed that customers selection of stores is also affected by attributes of retail stores visited (Al-Ali, 2015). Customer with store loyalty created through store attractiveness will have a mind sets of purchasing goods without any intention. There is a likelihood of making impulse buying through loyalty created via store attractiveness. Therefore, researchers hypothesize the followings;

$\mathrm{H}_{3}$ : Store attractiveness at store positively influence the customers' loyalty.

$\mathrm{H}_{3 \mathrm{a}}$ : Store attractiveness at the store positively influence the impulse buying at the store

$\mathrm{H}_{3 \mathrm{~b}}$ : Loyalty complementarily mediates between store attractiveness and impulse buying at retail stores

\subsection{Corporate Social Responsibility}

CSR activities have received its significance in the business world. Although it has multi dimensions (Salmones et al., 2005), retailers need to focus on the cause related marketing. CSR activities in retailing influence on consumer behaviour and brand loyalty (Jones et al., 2007). Corporate social responsibility is one of the integral components of the retails and help promote retail brand and market products (Jones et al., 2005). Further, CSR activities help retailers to create patronage intention and loyalty (Mandhachitara and Poolthong, 2011). Although it was also found that CSR is influencing loyalty mediating through trust (Choi \& La, 2013), CSR is also positively exerting an influence the brand loyalty (Martinez et al., 2014). Retailers also gain the benefits from the CSR in terms of creating brand awareness, corporate image, and brand equity (Hafez, 2018).

While discussing about the corporate social responsibility, it is clear that CSR will have definite advantage for the retailers as it positively influences the behavioural intention of customers (Chatzoudes et al., 2015). Therefore, when the customer and people experience the corporate social responsibility activities, store loyalty will be created and consequently, impulse buying may emerge. Thus, the following hypotheses are proposed.

$\mathrm{H}_{4}$ : CSR of retail store positively influence the customers' loyalty.

$\mathrm{H}_{4 \mathrm{a}}$ : CSR of retail store positively influence the impulse buying at the store

$\mathrm{H}_{4 \mathrm{~b}}$ : Loyalty complementarily mediates between CSR and impulse buying at retail stores

\subsection{Customers' Loyalty and Impulse Buying}

Loyalty helps retailers to enjoy competitive advantage (Mandhachitara \& Poolthong, 2011) and is important factor determining business success (Gable et al., 2008). Store loyalty will be enhanced with the help of loyalty program service quality consisting of factors such as reward, personalization, usefulness of information, quality of communication, courteousness and tangibility. Of these dimensions of quality, all dimension except personalization influence positively the store loyalty indirectly (Omar et al., 2013). Retailers' brand image is also one of the most important aspects in creating the loyalty towards retailers. Hence, it is also essential to the retailers to build their brand image and to realize the positive outcome of customers' loyalty (Ogba \& Tan, 2009).

Impulse buying take place when a store has enjoying shopping experience and this impact on the impulse buying positively (Atulkar \& Kesari, 2018). This means that a shopping environment should have music, lights, employees and layouts (Mohan et al., 2013). Literature suggests that store attractiveness, retailers' trust, commitment lead to store loyalty. When the store loyalty is created, there is a possibility of purchasing impulsively as there will not be any intention to purchase and without any intention, customers will be ready to purchase. Therefore, the following hypothesis is formulated.

$\mathrm{H}_{5}$ : Store loyalty of retailers positively lead to impulse buying

\section{Methodology}

The study was conducted in order to investigate influences of commitment, trust, CSR and store attraction on the loyalty and how the loyalty mediate between drivers of impulse buying and impulse buying at retail stores. This study was conducted in three districts namely Ampara, Batticaloa and Trincomalee. As this study involved in hypotheses testing and is an empirical study, positivism is adopted as research philosophy. The research approach is deductive as it is related to testing a theory through theoretical framework with the support of previous literature. The research strategy is survey methodology and time horizon is cross sectional.

\subsection{Survey Instrument}

Survey instrument for this study has been developed based on previous researchers. Statements in the 
questionnaire were measured with seven points Likert scale ranging from strongly disagree to strongly agree. Items adaptations for this study are shown in Table 1.

Table 1. Items Adaptations

\begin{tabular}{ccl}
\hline Variables & No. of Items & \multicolumn{1}{c}{ Adopted from } \\
\hline Commitment & 7 & Hennig-Thurau et al. (2002) and Smith (1998) \\
Trust & 4 & Srinivasan et al. (2002) \\
Store attraction & 5 & Gonzalez-Hernandez and Orozco-Gomez (2012) \\
CSR & 4 & Bigne et al. (2005) \\
Loyalty & 5 & Zeithaml et al. (1996); Plank and Newell (2007) \\
Impulse buying & 6 & Mittal et al. (2016) \\
\hline
\end{tabular}

Note: Items considered for this study are given in Table 5.

\subsection{Sample Selection and Data Collection}

This study focuses on the drivers such as commitment, trust, store attractiveness and CSR activities of retailers and mediating role of loyalty to trigger impulse buying respondents should be the customers. These respondents are from Ampara, Baticaloa and Trincomalee districts of Eastern province of Sri Lanka. Since all customers who experience retail stores are the sampling frame, convenience sampling technique was adopted. Researcher visited all these areas for data collection purpose. In addition, questionnaires were also issued through email and Facebook. The questionnaires were prepared in all three languages such as Tamil, Sinhala and in English. Finally, researcher was able obtain 529 filled questionnaires and were taken for analysis. Smart PLS3 was used to analyze the data collected for this purpose.

\section{Results}

Of 529 respondents, $71.6 \%$ of the respondents were male and $28.4 \%$ of them were female. $15.1 \%$ of the respondents' income was above Rs. 100,000. In the case of respondents age, $64.6 \%$ of the customers belong to the category of 41-60 years of age. Demographical Profile of the respondents are given in Table 2.

Table 2. Demographical Profile of Respondents

\begin{tabular}{lll}
\hline Characteristics & & $\%$ \\
\hline \multirow{2}{*}{ Sex } & Male & $71.6 \%$ \\
& Female & $28.4 \%$ \\
Age & $18-25$ & $5.1 \%$ \\
& $26-40$ & $22.7 \%$ \\
& $41-60$ & $64.6 \%$ \\
Income & $>60$ & $7.6 \%$ \\
& $<$ Rs. 50,000 & $12.7 \%$ \\
& Rs. $50,000-$ Rs. 100,000 & $72.2 \%$ \\
& $>$ Rs. 100,000 & $15.1 \%$ \\
Qualifications & Less than GCE O/L & $14.9 \%$ \\
& GCE O/L & $30.6 \%$ \\
& GCE A/L & $20.5 \%$ \\
& Graduates & $18.4 \%$ \\
& Postgraduates & $12.8 \%$ \\
\hline
\end{tabular}

Before analyzing the data collected from the respondents, it is necessary to validate the model obtained using SmpartPLS 3. As the first step of validating the results, construct reliability and validity is given in Table 3 .

Table 3. Construct Reliability and Validity

\begin{tabular}{ccccc}
\hline & Cronbach's Alpha & rho_A & Composite Reliability & Average Variance Extracted (AVE) \\
\hline CSR & 0.622 & 0.703 & 0.840 & 0.724 \\
Commitment & 0.560 & 0.701 & 0.762 & 0.517 \\
Impulse buying & 0.943 & 0.943 & 0.972 & 0.946 \\
Loyalty & 0.844 & 0.846 & 0.907 & 0.765 \\
Store attractiveness & 0.762 & 0.876 & 0.861 & 0.683 \\
Trust & 0.500 & 0.720 & 0.777 & 0.644 \\
\hline
\end{tabular}


According to Table 3, composite reliability is more than 0.70 and therefore, the model is reliable (Hair et al., 2013). It is also confirmed that convergent validity is also confirmed with the average variance extracted is more than 0.50 .

Having confirmed the convergent validity, it is necessarily required to confirm the discriminant validity of the model. For this purpose, Fornel and Larcker criterion is confirmed in the SmartPLS 3. This is given in Table 4.

Table 4. Fornel and Larcker Criterion

\begin{tabular}{ccccccc}
\hline & CSR & Commitment & Impulse buying & Loyalty & Store attractiveness & Trust \\
\hline CSR & $\mathbf{0 . 8 5 1}$ & & & & & \\
Commitment & 0.810 & $\mathbf{0 . 7 1 9}$ & & & & \\
Impulse buying & 0.856 & 0.726 & $\mathbf{0 . 9 7 3}$ & & & \\
Loyalty & 0.909 & 0.707 & 0.779 & $\mathbf{0 . 8 7 5}$ & 0.890 & $\mathbf{0 . 8 2 6}$ \\
Store attractiveness & 0.802 & 0.680 & 0.620 & 0.519 & $\mathbf{0 . 8 0 2}$ \\
Trust & 0.695 & 0.447 & 0.872 & 0.660 & 0.519 \\
\hline
\end{tabular}

Table 4 provides that the coefficient is not more than the square root of the average variance extracted. According to Table 4, there is no evidences of lack of discriminant validity. Discriminant validity is also confirmed with factorial loadings of the observed variables are greater than the other. Factorial loadings are given in Table 5.

Table 5. Factorial Loadings

\begin{tabular}{clcc}
\hline Items & Constructs & Factor Loadings & VIF \\
\hline C2 & Importance of relationship & 0.756 & 1.090 \\
C3 & Maximum effort to maintain relationship & 0.659 & 1.284 \\
C7 & Relationship as long term partnership & 0.738 & 1.232 \\
CSR1 & Protection of the environment & 0.818 & 1.256 \\
CSR3 & Participating in social and cultural events & 0.883 & 1.256 \\
IB5 & If I see difference, need to buy & 0.973 & 4.881 \\
IB6 & Feeling happy if I buy impulsively & 0.972 & 4.881 \\
L3 & Encouraging family and friend to buy at this retailer & 0.909 & 3.462 \\
L4 & Retailer is first choice if I think of shopping & 0.793 & 1.480 \\
L5 & I am loyal & 0.916 & 3.623 \\
SA1 & Retailer has variety of brands and category & 0.927 & 2.764 \\
SA3 & Assistants are very kind & 0.574 & 1.202 \\
SA4 & General decoration of the store & 0.926 & 2.643 \\
T1 & Will not switch to another retailer & 0.636 & 1.125 \\
T3 & This retailer is best one to do shopping & 0.939 & 1.125 \\
\hline
\end{tabular}

Table 5 provides the VIF values are more than 0.2 and not more than 5 (Hair et al., 2017). This is also one of the requirements for structural model evaluation.

\subsection{Path Coefficient and Hypotheses Testing}

Table 6 gives details about the direct effect of the commitment, trust, store attractiveness, and corporate social responsibility on the customers' loyalty and on the impulse buying.

Table 6. Direct Effects

\begin{tabular}{cccccc}
\hline & \multicolumn{3}{c}{ Model 1 } & \multicolumn{2}{c}{ Model 2 } \\
\cline { 2 - 6 } Variable & \multicolumn{3}{c}{ Loyalty } & \multicolumn{2}{c}{ Impulse buying } \\
\cline { 2 - 6 } CSR & Coefficient & $\boldsymbol{t}$ - value & $\boldsymbol{f}^{\mathbf{2}}$ & Coefficient & $\boldsymbol{t}$ - value \\
\hline Commitment & 0.568 & 13.394 & 0.519 & 0.442 & 11.671 \\
Store attractiveness & -0.101 & 3.574 & 0.035 & -0.079 & 3.496 \\
Trust & 0.468 & 20.589 & 0.824 & 0.365 & 23.013 \\
$\mathrm{R}^{2}$ & 0.068 & 2.822 & 0.023 & 0.053 & 0.607 \\
Adj. $\mathrm{R}^{2}$ & & 0.906 & & 0.606 \\
$f^{2}$ for Loyalty $\rightarrow$ Impulse buying & & 0.905 & & & \\
\hline
\end{tabular}

Note: $\mathrm{p}<0.05$ 
Table 6 provides the direct effect of latent variables CSR, commitment, store attractiveness and trust on loyalty and on impulse buying. All variables except commitment positively impact on the customers' loyalty as it has $t$ values are greater than 1.96 and $p$ value are less than $0.05(t>1.96, p<0.05)$. All effect sizes $\left(f^{2}\right)$ are more than 0.02 which means that there are effects on the endogenous variable loyalty. Despite the fact that the model is significant, path coefficient for the commitment is negative. Therefore, $\mathrm{H}_{2}, \mathrm{H}_{3}$ and $\mathrm{H}_{4}$ are supported and $\mathrm{H}_{1}$ is not supported as it is with negative path coefficient (Path coefficient $=-0.101, t>1.96, p<0.05$ ).

Table 6 shows that $90.6 \%$ of the variation of the loyalty of the retailers in Sri Lanka is explained by store attractiveness, CSR, trust and commitment. How the exogenous latent variables contribute to the $\mathrm{R}^{2}$ values is shown by $f^{2}$ values. Store attractiveness is having significant effect on the $\mathrm{R}^{2}$ value of model 1 . The second contribution by CSR and the third is turst and lastly the commitment negatively contributes to the $\mathrm{R}^{2}$ value of model $1 . \mathrm{Q}^{2}$ of the model 1 is 0.638 which is greater than zero and hence, the model accuracy is also accepted. Table 7 gives about $q^{2}$ values for all variables which reflects effect size on $\mathrm{Q}^{2}$ value.

Table 7. $q^{2}$ Values of Latent Variables

\begin{tabular}{ll}
\hline Latent variables & $q^{2}$ \\
\hline CSR & 0.202 \\
Commitment & 0.092 \\
Impulse buying & 0.607 \\
Loyalty & 0.478 \\
Store attractiveness & 0.391 \\
Trust & 0.067 \\
\hline
\end{tabular}

According to Table 7, all $q 2$ values are more than 0.02 and the constructs has predictive relevance endogenous constructs.

According to Model 2 of Table 2, shows the direct effect of the CSR, commitment, Store attractiveness and trust on the impulse buying. Except latent variable commitment, all other variables positively impact on the impulse buying at the retailers. It is also shown that $60.7 \%$ of the variation is explained by loyalty created through CSR, Commitment, trust, and store attractiveness in impulse buying at retail outlets. $Q^{2}$ value of the model 2 is 0.545 which is greater than zero and therefore, the model is accepted. Thus, $\mathrm{H}_{2 \mathrm{a}}, \mathrm{H}_{3 \mathrm{a}}$ and $\mathrm{H}_{4 \mathrm{a}}$ are supported. However, $\mathrm{H}_{1 \mathrm{a}}$ is not supported as it has negative path coefficient.

\subsection{Mediating Effects of Loyalty}

Mediating effect of customers' loyalty is important factor impacting the impulse buying at retail stores. In order to analyze the mediation effects, it is essential to investigate the indirect effects of the variables. Table 7 provides details about total indirect effects of variables.

Table 7. Total Indirect Effects

\begin{tabular}{cccc}
\hline & Path Coefficient & T Statistics $(|\mathrm{O} / \mathrm{STDEV}|)$ & P Values \\
\hline CSR -> Impulse buying & 0.442 & 11.671 & 0.000 \\
Commitment -> Impulse buying & -0.079 & 3.496 & 0.001 \\
Loyalty -> Impulse buying & 0.779 & 46.109 & 0.000 \\
Store attractiveness -> Impulse buying & 0.365 & 23.013 & 0.000 \\
Trust -> Impulse buying & 0.053 & 2.847 & 0.005 \\
\hline
\end{tabular}

Variables such as CSR (Path coefficient $=0.568, t>1.96, p<0.05$ ), store attractiveness (Path Coefficient $=$ $0.468, t>1.96, p<0.05$ ) and trust (Path coefficient $=0.068, t>1.96, p<0.05$ ) positively influence the customers' loyalty in Sri Lanka. In addition, it also evidently shows that variables such as CSR (Path coefficient $=0.442, t>1.96, p<0.05$ ), store attractiveness (Path coefficient $=0.365, t>1.96, p<0.05$ ) and trust (Path coefficient $=0.053, t>1.96, p<0.05$ ). Thus, customers' loyalty is taking the role of complementary mediation between the latent variables CSR, store attractiveness and trust, and impulse buying. In the case of mediation between commitment and impulse buying, loyalty takes the role of competitive mediation as negative path coefficient that is significant (Path coefficient $=-0.101, t>1.96, p<0.05$ ). Based on the analysis, Table 8 provides details about the mediation effect.

Further, it is also found that loyalty significantly contribute to the impulse buying at retail stores (Path coefficient $=0.779, t>1.96, p<0.05$ ) and therefore, $\mathrm{H}_{5}$ is supported. This structural model is given in Figure 1 . 
Table 8. Mediation Effects

\begin{tabular}{ccc}
\hline Hypotheses & Relationship & Results \\
\hline$H_{1 b}$ & $\mathrm{C}-->\mathrm{L}-->\mathrm{IB}$ & Not supported \\
$H_{2 b}$ & $\mathrm{~T}-->\mathrm{L}-->\mathrm{IB}$ & Supported \\
$H_{3 b}$ & $\mathrm{SA} \mathrm{-->} \mathrm{L} \mathrm{-->IB}$ & Supported \\
$H_{4 b}$ & $\mathrm{CSR}->>\mathrm{L}-->\mathrm{IB}$ & Supported \\
\hline
\end{tabular}

C-Commitment, L-Loyalty, IB-Impulse Buying, SA-Store attractiveness, CSR-Corporate Social Responsibility

\section{Discussion, Conclusion and Managerial Implication}

The major objective of this study was to examine the impact of drivers of impulse buying on the customers' loyalty. The other objective was to assess the mediating role of customers' loyalty created by CSR, trust, store attractiveness and commitment, to the impulse buying at the retail stores. Accordingly, findings reveal that corporate social responsibility, store attractiveness and trust are positively impacting the customers' loyalty. The loyalty positively associates with impulse buying at retail stores. Commitment is negatively contributing to the loyalty and it has positive relationship with impulse buying.

Findings suggest that the model containing commitment, trust, store attractiveness and corporate social responsibility mediate through loyalty which is positively impact on impulse buying of consumers at the retail outlets. The first latent variable that will have a positive impact on the customers' loyalty is corporate social responsibility (Path coefficient $=0.568, t>1.96, p<0.05$ ). This infers that retailers should engage in activities relevant to the corporate social responsibility. When retailers engage in CSR, customers' loyalty among the customers will be enhanced and that will cause impulse buying at the retail outlets. Finding reveals that engaging in safeguarding environment and participate in social and cultural events will boost the loyalty and motivate customer to buy impulsively in a retail environment. Retailers need to engage in CSR activities to improve their loyalty thereby improve or increase impulse buying which is one of the important sources of competitive advantage for retail stores. As suggested by Kim et al., (2014), retailers can engage in community and employee-oriented CSR campaigns.

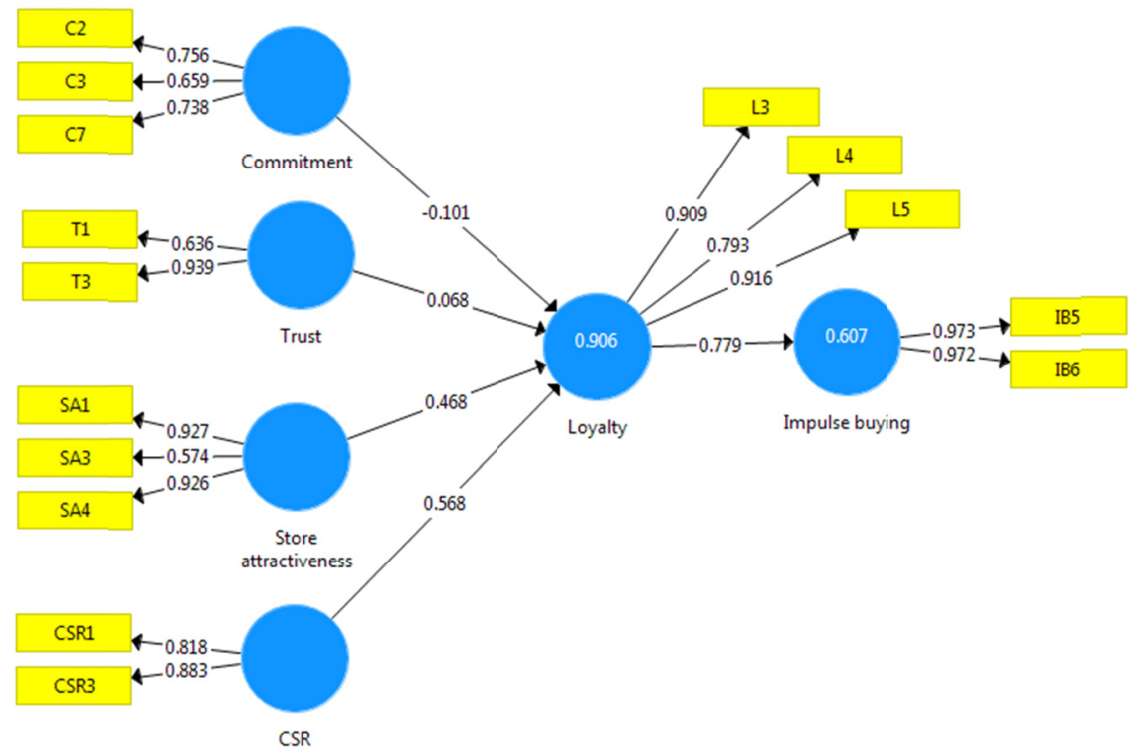

Figure 1. Structural Model

The second characteristic that positively influence the customers' loyalty is store attractiveness (Path coefficient $=0.468, t>1.96, p<0.05$ ). Retailers having more brands and variety of product category enhances retailer's loyalty. Sales assistants who work in retail stores with attributes of kindness and polite as it leads to customers' loyalty and is likely to create impulse buying at retail stores. Further, findings also reveal that decoration at the retail stores will also positively impact on the loyalty and that will lead to the impulse purchasing. Retailers also invest in store attraction of their stores. Store attraction should be focused by retailers as it determines revisit intention of customers and also create word of mouth (Saarijarvi et al., 2013).

The third factor that positively influence the customers' loyalty is trust (Path coefficient $=0.068, t>1.96, p<$ 
0.05). Specifically, customers are not thinking of switching to others and the particular retailer should be the first choice when making purchasing decision. This will help enhance the customers' loyalty and lead to impulse buying.

While trust, CSR and store attractiveness positively impacting the loyalty, loyalty plays a mediating role to make customers engaged in impulse buying. Retailers need to invest more on loyalty factors that would beef up the loyalty and if happened so, impulse buying can be formed among the customers visiting at the retail stores. Generally speaking, retailers should be able to induce customers to shopping with their friends and family. The brand of the retailers should be placed at the top of mind brand of customers. This can be established when retailers attempt to engage in corporate social responsibility activities, building up trust and increasing store attractiveness of their retails' stores.

In contrast to many literatures (for example Tabrani et al., 2018; Melewar et al., 2017), commitment is negatively influencing the loyalty in this study. This may be due to cultural settings of the country. Therefore, it is recommended that retailers need to focus more on commitment that positively contributes to the customers' loyalty. Hence, it can be suggested that retailers should take measures to establish profitable relationship with customers and maintain long term partnership with customers.

This study also contributes to the literature by supporting to the study explaining the relationship between store attractive dimensions and shopping loyalty (Wahlberg, 2016). Further, this study also supports Dagger et al., (2010) by exhibiting empirical evidences of association between trust and loyalty. The study also contributes to the literature by way of contributing to the study of Raza et al., (2018) and Perez and del Bosque (2014) demonstrating the positive relationship between CSR and loyalty.

The model tested in this study is significant and useful for the retailers to create loyalty and trigger impulse buying helping achieve competitive advantage in retailing. When retailers adopt this model in their business, retailers can establish loyalty and generate impulse buying enabling them to enjoy competitive advantage in the industry. Therefore, retailers need to build up trust among customers, engaging in CSR activities, keeping their stores very attractive and having long term relationship to create commitment with customers.

\section{Limitations and Direction for Future Studies}

The major limitation is sample of 529 respondents. Studies of this nature require larger samples size. This study was conducted in the Eastern part of the country and therefore, if it is extended to other areas of the country, results may be more reliable and can further be validated. Another limitation is filling out questionnaires. Respondents were hesitant to fill out or provide answers to the questionnaires in face to face contact. However, researcher was able to manage the respondents.

Finding studies of this nature in Sri Lankan context is very rare and therefore, it could further be extended consisting of other metropolitan cities in Sri Lanka. Thus, further studies can be conducted extending or increasing samples from other areas in Sri Lanka. Further studies can also be directed by incorporating variables such as marketing communication and service quality dimensions and this may provide more values to the research by exploring loyalty and impulse buying.

\section{References}

Abbes, M., \& Goudey, A. (2015). How salespersons induce trust between consumers and retailers: The case of French well-being stores. International Journal of Retail \& Distribution Management, 43(12), 1104-1125. https://doi.org/10.1108/IJRDM-06-2014-0064

Akhgari, M., Bruning, E. R., Finlay, J., \& Bruning, N. S. (2018). Image, performance, attitudes, trust, and loyalty in financial services. International Journal of Bank Marketing, 36(4), 744-763. https://doi.org/10.1108/IJBM-06-2017-0118

Al-Ali, M., Bazin, N. E. N., \& Shamsuddin, S. M. (2015). Key Determinants of Customer Satisfaction: Evidence from Malaysia Grocery Stores. Journal of Theoretical and Applied Information Technology, 74(3), 286-299

Anderson, E., \& Weitz, B. (1992). The use of pledges to build and sustain commitment in distribution channels. Journal of Marketing Research, 29(1), 18-34. https://doi.org/10.1177/002224379202900103

Anselmsson, J. (2006). Sources of customer satisfaction with shopping malls: A comparative study of different customer segments. The International Review of Retail, Distribution and Consumer Research, 16(1), 115-138. https://doi.org/10.1080/09593960500453641

Atulkar, S., \& Kesari, B. (2018). Role of consumer traits and situational factors on impulse buying: Does gender matter? I. J. of Retail \& Distribution Manag., 46(4), 386-405. https://doi.org/10.1108/IJRDM-12-2016-0239 
Babin, B. J., \& Attaway, J. S. (2000). Atmospheric affect as a tool for creating value and gaining share of customer. Journal of Business Research, 49(2), 91-99. https://doi.org/10.1016/S0148-2963(99)00011-9

Badgaiyan, A. J., \& Verma, A. (2014). Intrinsic factors affecting impulsive buying behaviour - evidence from India. J. of Retailing \& Consumer Services, 21(4), 537-549. https://doi.org/10.1016/j.jretconser.2014.04.003

Beatty, S. E., \& Ferrell, M. E. (1998). Impulse buying: Modeling its precursors. Journal of Retailing, 74(2), 169-191. https://doi.org/10.1016/S0022-4359(99)80092-X

Bigne, J. E., Andreu, L., Chumpitaz, R., \& Swaen, V. (2005). Perception de la responsabilidad social corporativa: An analisis cross-cultural. Universia Business Review, (5), 14-27.

Brici, N., Hodkinson, C., \& Mort, G. S. (2013). Conceptual differences between adolescent and adult impulse buyers. Young Consumers, 14(3), 258-279. https://doi.org/10.1108/YC-01-2013-00340

Chatzoudes, D., Papadopoulos, D., \& Dimitriadis, E. (2015). Investigating the impact of corporate social responsibility (CSR) policies: An empirical research. International Journal of Law and Management, 57(4), 265-280. https://doi.org/10.1108/IJLMA-09-2013-0041

Choi, B., \& La, S. (2013). The impact of corporate social responsibility (CSR) and customer trust on the restoration of loyalty after service failure and recovery. Journal of Services Marketing, 27(3), 223-233. https://doi.org/10.1108/08876041311330717

Dagger, T. S., David, M. E., \& Ng, S. (2011). Do relationship benefits and maintenance drive commitment and loyalty? Journal of Services Marketing, 25(4), 273-281.

Dagger, T. S., \& O'Brien, T. K. (2010). Does experience matter?: Differences in relationship benefits, satisfaction, trust, commitment and loyalty for novice and experienced service users. European Journal of Marketing, 44(9/10), 1528-1552.

Deng, Z. L. S., \& Moutinho, L. (2015). The Impact of Experience Activities on Tourist Impulse Buying: An Empirical Study in China. Asia Pacific Journal of Tourism Research, 20(2), 191-209, https://doi.org/10.1080/10941665.2013.877043

Dey, D. K., \& Srivastava, A. (2017). Impulse buying intentions of young consumers from a hedonic shopping perspective. J. of Indian Business Research, 9(4), 266-282. https://doi.org/10.1108/JIBR-02-2017-0018

El-Adly, M. I. (2007). Shopping malls attractiveness: A segmentation approach. International Journal of Retail \& Distribution Management, 35(11), 936-950. https://doi.org/10.1108/09590550710828245

Gable, M., Fiorito, S. S., \& Topol, M. T. (2008). An empirical analysis of the components of retailer customer loyalty programs. International Journal of Retail \& Distribution Management, 36(1), 32-49. https://doi.org/10.1108/09590550810846983

González-Hernández, E. M., \& Orozco-Gómez, M. (2012). A segmentation study of Mexican consumers based on shopping centre attractiveness. International Journal of Retail \& Distribution Management, 40(10), 759-777. https://doi.org/10.1108/09590551211263173

Guenzi, P., Johnson, M. D., \& Castaldo, S. (2009). A comprehensive model of customer trust in two retail stores. Journal of Service Management, 20(3), 290-316. https://doi.org/10.1108/09564230910964408

Hafez, M. (2018). Measuring the impact of corporate social responsibility practices on brand equity in the banking industry in Bangladesh: The mediating effect of corporate image and brand awareness. International Journal of Bank Marketing, 36(5), 806-822. https://doi.org/10.1108/IJBM-04-2017-0072

Hair, J. F., Hult, G. T. M., Ringle, L. M., \& Sarstedt, M. (2017). Primer on Partial Least Squares Structural Equation Modeling (PLS-SEM) (2nd ed.). SAGE Publication, USA.

Hausman, A. (2000). A multi-method investigation of consumer motivations in impulse buying behavior. Journal of Consumer Marketing, 17(15), 403-419. https://doi.org/10.1108/07363760010341045

Hennig-Thurau, T., Gwinner, K. P., \& Gremler, D. D. (2002). Understanding relationship marketing outcomes: An integration of relational benefits and relationship quality. Journal of Service Research, 4(3), 230-247. https://doi.org/10.1177/1094670502004003006

Hilal, M. I. M., \& Mubarak, K. M. (2015). Influence of Selected Groceries' Marketing Mix Elements on Business Performance in the Eastern Province of Sri Lanka: Retailers' Perspective. International Journal of Business Performance Management, 16(2/3), 198-213. https://doi.org/10.1504/IJBPM.2015.068712

Hur, W. M., Ahn, K. H., \& Kim, M. (2011). Building brand loyalty through managing community commitment. 
Management Decision, 49(7), 1194-1213. https://doi.org/10.1108/00251741111151217

Jones, T., Fox, G. L., Taylor, S. F., \& Fabrigar, L. R. (2010). Service customer commitment and response. Journal of Services Marketing, 24(1), 16-28. https://doi.org/10.1108/08876041011017862

Jones, P., Comfort, D., \& Hillier, D. (2005). Corporate social responsibility as a means of marketing to and communicating with customers within stores: A case study of UK food retailers. Management Research News, 28(10), 47-56. https://doi.org/10.1108/01409170510785011

Jones, P., Comfort, D., \& Hillier, D. (2007). What's in store? Retail marketing and corporate social responsibility. Marketing Intelligence \& Planning, 25(1), 17-30. https://doi.org/10.1108/02634500710722371

Ju, J., \& Ahn, J. (2016). The effect of social and ambient factors on impulse purchasing behavior in social commerce. Journal of Organizational Computing and Electronic Commerce, 26(4), 285-306. https://doi.org/10.1080/10919392.2016.1228353

Kandampully, J. (2006). Service Management: The Paradigm in Retailing. NY, Dordrecht Heidelberg London.

Kaur, H., \& Soch, H. (2018). Satisfaction, trust and loyalty: Investigating the mediating effects of commitment, switching costs and corporate image. Journal of Asia Business Studies, 12(4), 361-380. https://doi.org/10.1108/JABS-08-2015-0119

Kim, J., Ha, S., \& Fong, C. (2014). Retailers' CSR: The effects of legitimacy and social capital. International J. of Retail \& Distribution Management, 42(2), 131-150, https://doi.org/10.1108/IJRDM-10-2012-0092

Mandhachitara, R., \& Poolthong, Y. (2011). A model of customer loyalty and corporate social responsibility. Journal of Services Marketing, 25(2), 122-133. https://doi.org/10.1108/08876041111119840

Martínez, P., Pérez, A., \& del Bosque, I. R. (2014). CSR influence on hotel brand image and loyalty. Academia Revista Latinoamericana de Administración, 27(2), 267-283. https://doi.org/10.1108/ARLA-12-2013-0190

McKnight, D. H., Choudhury, V., \& Kacmar, C. (2002). Developing and validating trust measures for e-commerce: An integrative typology. Information Systems Research, 13(3), 334-359.

Melewar, T. C., Foroudi, P., Gupta, S., Kitchen, P. J., \& Foroudi, M. M. (2017). Integrating identity, strategy and communications for trust, loyalty and commitment. European Journal of Marketing, 51(3), 572-604. https://doi.org/10.1108/EJM-08-2015-0616

Mittal, S., Chawla, D., \& Sondhi, N. (2016). Impulse buying tendencies among Indian consumers: Scale development and validation. Journal of Indian Business Research, 8(3), 205-226. https://doi.org/10.1108/JIBR-09-2015-0101.

Mohan, G., Sivakumaran, B., \& Sharma, P. (2013). Impact of store environment on impulse buying behavior. European Journal of Marketing, 47(10), 1711-1732. https://doi.org/10.1108/EJM-03-2011-0110

Nayebzadeh, S., \& Jalaly, M. (2014). Investigating Iranian female Muslim consumer impulse buying behaviour used as a form of retail therapy. Journal of Islamic Marketing, 5(2), 302-320. https://doi.org/10.1108/JIMA-05-2012-0029.

Ogba, I. E., \& Tan, Z. (2009). Exploring the impact of brand image on customer loyalty and commitment in China. J. of Technology Management in China, 4(2), 132-144. https://doi.org/10.1108/17468770910964993

Omar, N. A., Wel, C. A. C., Aziz, N. A., \& Alam, S. S. (2013). Investigating the structural relationship between loyalty programme service quality, satisfaction and loyalty for retail loyalty programmes: Evidence from Malaysia. Measuring Business Excellence, 17(1), 33-50. https://doi.org/10.1108/13683041311311356.

Palmatier, R. W., Dant, R. P., Grewal, D., \& Evans, K. R. (2006). Factors influencing the effectiveness of relationship marketing: A meta-analysis. Journal of Marketing, 70, 136-153. https://doi.org/10.1509/jmkg.70.4.136

Pérez, A., \& del Bosque, I. R. (2015). Corporate social responsibility and customer loyalty: Exploring the role of identification, satisfaction and type of company. Journal of Service Marketing, 29(1), 15-25. https://doi.org/10.1108/JSM-10-2013-0272

Plank, R. E., \& Newell, S. J. (2007). The effect of social conflict on relationship loyalty in business markets. Industrial Marketing Management, 36(1), 59-67. https://doi.org/10.1016/j.indmarman.2005.03.012

Rampl, L. V., Eberhardt, T., Schütte, R., \& Kenning, P. (2012). Consumer trust in food retailers: Conceptual framework and empirical evidence. International Journal of Retail \& Distribution Management, 40(4), 254-272. https://doi.org/10.1108/09590551211211765 
Raza, A., Bhutta, U. S., Iqbal, M. H., \& Faraz, N. A. (2018). Corporate Social Responsibility and Customer Loyalty: A Mediating Role of Trust. European Journal of Business and Social Sciences, 7(1), 43-50. https://doi.org/10.1007/s11747-008-0117-x

Ring, P. S., \& Van de Ven, A. H. (1994). Developmental processes of cooperative interorganizational relationships. Academy of Management Review, 19(1), 90-118.

Robert, J. A., \& Manolis, C. (2012). Cooking Up a Recipe for Self- Control: The Three Ingredients of Self-Control and its Impact on Impulse Buying. Journal of Marketing Theory and Practice, 20(2), 173-188.

Saarijärvi, H., Rintamäki, T., \& Kuusela, H. (2013). Facilitating customers' post-purchase retail experiences. British Food Journal, 115(5), 635-665. https://doi.org/10.1108/00070701311331562

Salmones, M. M., Crespo, A. H., \& Bosque, I. R. I. (2005). Influence of corporate social responsibility on loyalty and valuation of services. Journal of Business Ethics, 61(4), 369-385.

Shainesh, G. (2012). Effects of trustworthiness and trust on loyalty intentions: Validating a parsimonious model in banking. International Journal of Bank Marketing, 30(4), 267-279. https://doi.org/10.1108/02652321211236905

Sharma, P., Sivakumaran, B., \& Marshall, R. (2010). Impulse buying and variety seeking: A trait-correlates perspective. Journal of Business Research, 63, 276-283. http://dx.doi.org/10.1016/j.jbusres.2009.03.013

Shuleska, A. C. (2012). The Impact of Situational, Demographic, and Socioeconomic Factors on Impulse Buying in the Republic of Macedonia. Journal of East-West Business, 18(3), 208-230. https://doi.org/10.1080/10669868.2012.706869

Smith, J. B. (1998). Buyer-seller relationships: Similarity, relationship management, and quality. Psychology and Marketing, 15(1), 3-21.

Srinivasan, S. S., Anderson, R., \& Ponnavolu, K. (2002). Customer loyalty in e-commerce: An exploration of its antecedents and consequences. Journal of Retailing, 78(1), 41-50. https://doi.org/10.1016/S0022-4359(01)00065-3

Tabrani, M., Amin, M., \& Nizam, A. (2018). Trust, commitment, customer intimacy and customer loyalty in Islamic banking relationships. International Journal of Bank Marketing, 36(5), 823-848. https://doi.org/10.1108/IJBM-03-2017-0054

Tandon, A., Gupta, A., \& Tripathi, V. (2016). Managing shopping experience through mall attractiveness dimensions: An experience of Indian metro cities. Asia Pacific Journal of Marketing and Logistics, 28(4), 634-649. https://doi.org/10.1108/APJML-08-2015-0127

Tendai, M., \& Crispen, C. (2009). In-store shopping environment and impulsive buying. African Journal of Marketing Management, 1(4), 102-108.

Tifferet, S., \& Herstein, R. (2012). Gender differences in brand commitment, impulse buying, and hedonic consumption. J. of Product \& Brand Manag, 21(3), 176-182. https://doi.org/10.1108/10610421211228793

Torlak, O., Uzkurt, C., \& Özmen, M. (2010). Dimensions of Service Quality in Grocery Retailing: A Case from Turkey. Management Research Review, 33(5), 413-422. https://doi.org/10.1108/01409171011041866

Tsao, W. U. (2013). Application of Expectation Confirmation Theory to Consumers' Impulsive Purchase Behavior for Products Promoted by Showgirls in Exhibits. Journal of Promotion Management, 19(3), 283-298. https://doi.org/10.1080/10496491.2013.770811

Tuan, L. T. (2012). Corporate social responsibility, leadership, and brand equity in healthcare service. Social Responsibility Journal, 8(3), 347-362. https://doi.org/10.1108/17471111211247929

Wahlberg, O. (2016). Small town centre attractiveness: Evidence from Sweden. International Journal of Retail \& Distribution Management, 44(4), 465-488. https://doi.org/10.1108/JJRDM-08-2014-0121

Zeithaml, V., Berry, L., \& Parasuraman, A. (1996). The behavioural consequences of service quality. Journal of Marketing, 60, 31-46. https://doi.org/10.1177/002224299606000203

\section{Copyrights}

Copyright for this article is retained by the author(s), with first publication rights granted to the journal.

This is an open-access article distributed under the terms and conditions of the Creative Commons Attribution license (http://creativecommons.org/licenses/by/4.0/). 